University of Rhode Island

DigitalCommons@URI

\title{
Whatever floats your vote: understanding voter support for public port infrastructure investments
}

Jarron VanCeylon

University of Rhode Island

Corey Lang

University of Rhode Island, clang@uri.edu

Austin Becker

University of Rhode Island, abecker@uri.edu

Follow this and additional works at: https://digitalcommons.uri.edu/maf_facpubs

\section{The University of Rhode Island Faculty have made this article openly available.}

Please let us know how Open Access to this research benefits you.

This is a pre-publication author manuscript of the final, published article.

Terms of Use

This article is made available under the terms and conditions applicable towards Open Access

Policy Articles, as set forth in our Terms of Use.

\section{Citation/Publisher Attribution}

Jarron VanCeylon, Corey Lang \& Austin Becker (2020) Whatever floats your vote: understanding voter support for public port infrastructure investments, Maritime Policy \& Management, DOI: 10.1080/ 03088839.2020 .1754478

Available at: https://doi.org/10.1080/03088839.2020.1754478

This Article is brought to you for free and open access by the Marine Affairs at DigitalCommons@URI. It has been accepted for inclusion in Marine Affairs Faculty Publications by an authorized administrator of DigitalCommons@URI. For more information, please contact digitalcommons@etal.uri.edu. 


\title{
Whatever Floats Your Vote: Understanding Voter Support for Public Port Infrastructure Investments
}

\author{
Jarron VanCeylon ${ }^{1}$, Corey Lang ${ }^{1}$, Austin Becker ${ }^{2}$ \\ ${ }^{1}$ Department of Environmental and Natural Resource Economics, University of Rhode Island; \\ ${ }^{2}$ Department of Marine Affairs, University of Rhode Island
}

\begin{abstract}
Ports are a cornerstone of the local, state, and national economy, especially for coastal cities. However, ports face growing economic challenges that require infrastructure financing, and a relevant avenue of securing funds is through government assistance via bond issues. We examine voter support for the public financing of port infrastructure investments using a 2016 referendum in Rhode Island. Through our multiple regression voting model, we find strong evidence that public spending on ports in Rhode Island was more of a bipartisan issue compared to other public financing efforts on the ballot. Additionally, neighborhoods with a larger minority presence and those with higher median per capita income were more likely to support port development. In contrast, areas with a higher homeowner population and those communities farther from ports were less likely to support port spending. As a key novelty to our paper, we use our voting model results to forecast how a hypothetical port infrastructure bond might fare in other states, and find that regardless of socioeconomic and political differences, all coastal states in the US would be expected to pass a port referendum.
\end{abstract}

\section{Keywords}

Port infrastructure, voting, public support, public spending, bond referendums, Rhode Island

To cite this article: Jarron VanCeylon, Corey Lang \& Austin Becker (2020): Whatever floats your vote: understanding voter support for public port infrastructure investments, Maritime Policy \& Management, DOI: 10.1080/03088839.2020.1754478 To link to this article: https://doi.org/10.1080/03088839.2020.1754478

*Corresponding author. Address: 214 Coastal Institute, 1 Greenhouse Rd., Kingston, RI, 02881. Email: clang@uri.edu. 


\title{
Whatever Floats Your Vote: \\ Understanding Voter Support for Public Port Infrastructure Investments
}

\begin{abstract}
Ports are a cornerstone of the local, state, and national economy, especially for coastal cities. However, ports face growing economic challenges that require infrastructure financing, and a relevant avenue of securing funds is through government assistance via bond issues. We examine voter support for the public financing of port infrastructure investments using a 2016 referendum in Rhode Island. Through our multiple regression voting model, we find strong evidence that public spending on ports in Rhode Island was more of a bipartisan issue compared to other public financing efforts on the ballot. Additionally, neighborhoods with a larger minority presence and those with higher median per capita income were more likely to support port development. In contrast, areas with a higher homeowner population and those communities farther from ports were less likely to support port spending. As a key novelty to our paper, we use our voting model results to forecast how a hypothetical port infrastructure bond might fare in other states, and find that regardless of socioeconomic and political differences, all coastal states in the US would be expected to pass a port referendum.
\end{abstract}

Keywords: Port infrastructure, voting, public support, public spending, bond referendums, Rhode Island 


\section{Introduction}

\subsection{State of Infrastructure, Projected Growth of Cargo Volumes, and Climate Change Impacts}

The 926 seaports in the U.S. facilitate $99 \%$ of overseas trade, which accounts for $26 \%$ of the U.S. economy and supports over 23 million jobs (U.S. Department of Transportation 2018). Ports are a cornerstone of the local, state, and national economy, especially for the coastal cities in which they are located. Despite the critical role they play in the economy, many ports suffer from aging infrastructure and capacity restrictions and are in need of major investment to keep up with demand (American Society of Civil Engineers 2017, Government Accountabiity Office 2012). In a recent survey, the American Association of Port Authorities (AAPA) found that $80 \%$ of U.S. ports anticipate at least $\$ 10$ million of investment (and 30\% anticipate at least $\$ 100$ million) will be needed to improve intermodal connectors through 2025 (American Association of Port Authorities 2015).

Ports are gateways for the movement of freight or passengers between waterways and landside infrastructure. They consist of infrastructure that includes berthing areas for ships, laydown areas for cargo, container cranes, warehouses, liquid bulk tanks, and more depending on what type of cargo they primarily handle. Typically, a public port authority takes responsibility for the maintenance and improvement of the structures and equipment on their land. However, a "port" in the broader sense of the term, consists of not only a public port lands, but also numerous private terminals and facilities that are located throughout an urban harbor. In Providence (RI), for example, 15 individual businesses directly depend on the functioning of the infrastructure in and around the Providence Harbor (Becker and Kretsch 2019).

In addition to the infrastructure located on the grounds of the port itself, ports depend on the road and highway system, rail connections, and deepwater channels for access to the sea. 
Responsibility for maintenance and capital improvements to the maritime transportation system, of which ports form one key node, rests with numerous private and public entities. In the US, the United States Army Corps of Engineers maintains navigation infrastructure, including deepwater channels, locks and dams, and storm barriers. The federal or state departments of transportation keep the bridges and highways maintained. Public railway authorities and private railway operators take responsibility for the freight rail system, and the Unites States Coast Guard takes responsibility for navigation system maintenance and enforcement of laws.

Today, ports face three key infrastructure maintenance and improvement challenges. First, port infrastructure is aging. In particular for smaller and medium sized ports, much of the infrastructure was built over 50 years ago and is at the end of its intended design life (Government Accountability Office 2012). Second, the demands on ports are increasing as cargo throughput grows and the size of ships increases. The new Panama Canal challenges ports to deepen their channels, increase the size of their cranes, and accommodate more trucks through their gates. Third, the growing threats of increased storms and sea level rise from climate change will force ports to make significant changes to their infrastructure to prevent recurrent damages from regular "sunny day flooding" and also from more intense storm surge (Becker et al. 2013). A 2015 survey of ports indicated a combined need of $\$ 28.9$ billion for 125 port-related projects (American Association of Port Authorities 2015).

Ports generally fund capital improvements through a combination of self-generated revenue and government assistance. In the US, many of the projects identified in the AAPA survey received or will receive federal TIGER grants. Others take advantage of the Transportation Infrastructure Finance and Innovation Act program. Many leverage the planning provisions of 
MAP-21 to partner ports with their local Metropolitan Planning Organizations or Freight Advisory Committees to help secure federal funding for infrastructure projects.

Even though ports have a multitude of financing options to choose from, one viable choice that ports may utilize more in the future is financing through public bond issues. These bond issues must be passed with the public's support, and knowing how different communities support port development at the ballot box is an important question for ports and other agencies who are looking to secure funds.

\subsection{Research Questions and Contributions}

We study voter support for public financing of port infrastructure investments in the case of the 2016 general election in Rhode Island which featured a specific port infrastructure bond issue. This paper relies on the ballot results of the port infrastructure bond and aggregate census data from the state of Rhode Island. With these data we construct a model in an attempt to explain the determinants of public support for port infrastructure. We present the results of our model in the pursuit of two questions that we believe will inform policy-makers going forward as the need for port infrastructure financing continues to grow.

Our first research question is: What types of people support public spending on port infrastructure? As ports face growing challenges that require infrastructure financing, a relevant avenue of securing funds is through government assistance via bond issues. Direct democracy settings allow voters to approve or deny such funding opportunities. Because securing these resources is paramount to ports for further development, identifying the types of people who support public spending on ports is relevant for the passage of these measures. By extension, 
knowing the primary indicators of support for port spending will give insight to the likelihood of passage for any proposed port infrastructure bond issues.

Our second research question is: Is publicly approved financing a viable source of revenue for port investment in the U.S.? State governments looking to use bond measures as a source of financing for port development may face several challenges garnering support from the public. Public support for port development has been largely unobserved as only a handful of portspecific bond measures have been held in the U.S. in the last decade. ${ }^{1}$ It is somewhat ambiguous how support for public spending on ports may change across different geographies. Differing socioeconomic and political ideologies across states may play a large role in a port bond's passage or failure.

We make several contributions to the literature with this paper. First, the application of a voting determinant model in a port infrastructure setting is, to the best of our knowledge, unique in itself and we hope will provide new insights in to individuals preferences for public spending on ports. Second, we use our results to project votes for other coastal states to forecast how a hypothetical port infrastructure bond might fare in other states.

This paper begins with a general overview of capital financing for port infrastructure and bond issues involving port specific measures. We then detail the literature and methods that led to the construction of our voting model as well as the data that was collected for our analysis. Next, we discuss the results of our voting model and the implications of our findings. We then acknowledge and discuss several limitations of our methods. Finally, our paper places our findings

\footnotetext{
${ }^{1}$ There have been five port related bond issues in Maine and one in Rhode Island since 2008, all of which have passed. Many bond issues are listed under transportation related ballot measures, and some transportation ballot measures did not list ports explicitly in the measure so this is an approximation ("Bond Issues").
} 
in context, briefly summarizes our results, and suggests how policy-makers may move forward given these new insights in public support for port spending.

\section{Background}

\subsection{Bonds as a Financing Mechanism}

Direct democracy allows the constituents of a state, county, or municipality to vote directly on a law or measure. While laws on direct democracy may differ across states, many types of ballot measures have been present in the U.S. and have been growing in popularity for many years. One route direct democracy might take for the allocation of public funds to development projects is bond referendums on the ballot. In general, a bond issue proposes a specific allocation of funds to a particular project or effort and is presented to the voters of a jurisdiction as a ballot measure. Bonds are typically chosen over taxes for large, immediate expenses such as infrastructure for schools or roads. Bonds are issued by the government to private investors in return for loans that the government must repay with accruing interest. For some types of bond issues appearing on the ballot, a repayment mechanism is specified such as tolls or fees. For other types of bonds, the government uses general revenue like sales or income tax (Matsusaka 2005).

\subsection{Rhode Island as "Proxy" and Port Related Bond Issues in the U.S.}

In an effort to examine how other states might vote on a hypothetical ballot, we use Rhode Island as a "proxy" to gauge how different communities may support a port infrastructure bond issue. 
The Rhode Island 2016 general election ballot included the presidential vote, two congressional representative votes, a legislatively referred state statute, a legislatively referred constitutional amendment, and five bond referendum questions. The bond issues that appeared on the ballot included measures for affordable housing, port infrastructure, a veterans' home, higher education jobs, and green economy bonds. While all bond issues passed at varying margins, the port infrastructure bond passed with $63.3 \%$ approval.

Question 5 in the general election ballot was titled "Rhode Island Port Infrastructure Bonds". This issue designated $\$ 70$ million dollars for infrastructure and land acquisition allocated across two ports. $\$ 50$ million was allocated for "Infrastructure modernization of Port Davisville at Quonset". The Port of Davisville at Quonset had previously been a Navy port, and now has two major piers used to offload automobiles, process seafood, and other activities. It is one of the top 10 car ports in the country and contributes over $\$ 300$ million to the state's economy (Raimondo 2016). The Davisville Port bond was born from the anticipated infrastructure and repair needs for the growing offshore wind farm industry and additional vessel activity. A portion of the Davisville Port funds will be used to extend Pier 2. An additional $\$ 20$ million of the bond would be allocated to the Port of Providence for the acquisition of up to 25 acres of land and any infrastructure improvements associated with the acquisition. The Port of Providence is one of two deepwater ports in New England and generates about \$200 million to the state's economy. It handles dry bulk (coal, salt, chemicals), petroleum products, used car exports, and other general cargo. Projections suggested that the expansion of the Port of Providence would create 300 new jobs and $\$ 2.45$ million in state and city taxes (Raimondo 2016). The exact wording appearing on the ballot for the port infrastructure question is depicted below. 


\begin{tabular}{|l|}
\multicolumn{1}{|c|}{ State Questions } \\
\hline $\begin{array}{l}\text { 5. Port Infrastructure Bonds - } \\
\mathbf{\$ 7 0 , 0 0 0 , 0 0 0}\end{array}$ \\
For port infrastructure projects, to be \\
allocated as follows: \\
(a) Port of Davisville Infrastructure at \\
Quonset \$50,000,000 \\
(b) Port of Providence Infrastructure \\
$\$ 20,000,000$
\end{tabular}

Rhode Island is unique in that it holds bond issues more often than most states. Since 2000, Rhode Island has held 49 bond issues. In comparison, New York has held five and Alabama has held four bond issues from 2000 to 2019. States like Rhode Island and Maine, which hold many bond issues every year, may differ from places like New York and Alabama where funding opportunities may be worked into their normal budgets. From 1950 to 2015 five out of the eight proposed bond issues involving port and pier infrastructure in Rhode Island passed with public approval (“Bond Issues”). In general, most states issue bonds for port infrastructure or development under "transportation" related ballot questions. Due to the infrequency of specific port infrastructure bonds, this case of Rhode Island provides a unique opportunity for analysis.

\subsection{Economic Benefits and Environmental Concerns}

Port expansion and infrastructure issues have been contested topics between law makers, $\underline{\text { stakeholders, and the Rhode Island community for decades. While investing resources into the }}$ ports may offer several economic benefits, there is a myriad of environmental concerns that $\underline{\text { Rhode Island locals are actively aware of and these concerns may be reflected in the poll results. }}$ Historical debate concerns The Port of Providence, due to its proximity to a major population 
center and environmental impacts of truck traffic and port operations. Additionally, in the early 2000's, Rhode Island Governor Lincoln Almond pushed for a proposal to turn the Port of Quonset/Davisville into a mega-container port. Ultimately, this effort was rejected due to environmental concerns of shellfishermen, local residents, and others.

ProvPort is a city-affiliated nonprofit entity that manages a portion of The Port of Providence through a contract with Waterson Terminal Services. Currently, it provides 1,700 jobs through the companies that lease ProvPort's land at the southern portion of the port area. Despite being one of the largest deepwater ports in New England, ProvPort faces increased demands and pressure to stay competitive with ports in Massachusetts and Connecticut. The approved bond would primarily be used for the acquisition of additional property, which would allow for new tenants and additional cargo storage with refrigeration capacity, keeping Rhode Island competitive with other states (Carini 2016). The development stemming from the 2016 referendum is expected to add 300 jobs and \$1.25 million dollars in annual tax revenue (Carini 2016)

$\underline{\text { Rhode Island community organizations have had long-standing concerns about the }}$ development of Narragansett Bay and potential environmental degradation. For example, the EPA reported in 2013 that a chemical manufacturer and ProvPort tenant released 1,275 pounds of chemicals into Providence's waterfront neighborhood. Further, the proposed expansion exacerbated fears. One of the proposed acquisition sites is a recycled metals scrapyard, which was previously cited for not following an environmental cleanup plan, reportedly contaminating local waters with polluted runoff and fuel from stored vessels (Anderson 2016). However, the bond has no language regarding clean up or alternative solutions if the scrap yard is acquired. 


\section{Well-informed voters will take into account these benefits and costs when deciding how}

$\underline{\text { to vote. }}$

\section{Data and Methods}

\subsection{Overview of Voting Models and Relevant Literature}

The allocation and provision of public goods is a collective decision. It is critical to understand how voters make decisions when faced with a referendum about public goods, given their value and importance.

Empirically, studying this voting behavior is challenging because individual voting decisions are not publicly available due to ballot confidentiality. However, aggregated votes are widely available and prior research has used this source of data matched with aggregate census data. Deacon and Shapiro (1975) pioneered using these data by constructing a model relating aggregate voting outcomes for public goods to a suite of demographic and socioeconomic attributes, in order to untangle the determinants of voting decisions.

Following this empirical logic, many researchers have examined various types of ballot measures and referendums in attempt to uncover different drivers of support for public goods. Environmental voting has been a common area of study using this approach, which makes sense given the importance of public, non-market goods in that arena. Kahn and Matsusaka (1997) examine voting behavior on 16 environmental ballot propositions in California and find evidence that various environmental amenities like air quality and preserved open space were strongly supported by those with average incomes. Additionally, they observe the effects of population density, industry, education and political ideology on referendum support many of which we include in our model. 
Several studies have shown that political party affiliation is a significant indicator of support for public goods, however, others report that the effect is ambiguous or non-significant. The majority of results suggest that more Democratic communities tend to support the allocation of funds for public goods, especially those related to the environment (Kahn and Matsusaka 1997, Nelson et al. 2007, Heintzelman et al. 2013, Altonji et al. 2016).

Wu and Cutter (2011) examine voting data for both environmental and non-environmental propositions. They find that both the educated, and Black and Hispanic communities tend to support environmental issues fairly consistently while their support for non-environmental propositions is less clear. In a paper by Heintzelman et al. (2013), they also suggests that higher educated communities are more likely to support environmental referendums.

In a similar vein of research Kotchen and Powers (2006) study the demographics and socioeconomic differences of various communities in an attempt to explain the probability of a local government holding a referendum for the preservation of open space, and then determining who would support these referenda. A major contributing factor of support for these referenda is the finance mechanism, suggesting that voters are much more likely to support bond issues opposed to a tax increase. Similarly, Nelson et al. (2007) find that a voter facing a referendum funded by an increased tax rate was $34 \%$ less likely to vote 'yes'.

While environmental voting has been the most common area of study, researchers have applied these methods to other areas as well. For example, Ahlfeldt and Manning (2015) study a public referendum on an airport reconfiguration measure in Germany to assess the disparity in voting behavior between homeowners and renters. Their results suggest that homeowners strongly oppose any initiatives that would negatively impact the value of their neighborhood, while renters voted in the opposite direction. 
Further, Matsa and Miller (2018) examine the types of communities that vote for the expansion of Medicaid in Maine. They find evidence that more educated areas are more likely to support Medicaid expansion, while higher income areas are more likely to vote against it. They then use these results to project votes for a hypothetical Medicaid expansion bill in other states. Similarly, we use our Rhode Island specific results to project votes for port infrastructure bonds in other states with the goal of uncovering nuances in public preferences for ports across the United States.

Public perceptions and voting on port infrastructure issues is not a widely covered topic to our knowledge. Studies have been done examining the public perception of coastal amenities like Munro et al. (2017) who institute a survey in Australia to gauge the 'public value' of various marine and coastal sites. Attempting to identify the differences between resident and non-resident preferences, they find that residents were more likely to choose general recreation areas while nonresidents chose biological conservation and wilderness areas.

In the realm of public financing of port projects, Vining and Boardman (2008) recognize the expanding role of the government in port expansion in their research. They propose that publicprivate partnerships will become a more popular option for governments due to the benefits they offer to the private sector, as well as government control over certain aspects of the port. Similarly, Baird (2004) examines European seaports and the classification of public goods. Baird suggests the need for a more cohesive policy when it comes to the justification for continued public spending on major port infrastructure projects due to the environmental concerns from mega-port expansions and long-term feasibility for equal development across the EU.

Our case of the port infrastructure bond in Rhode Island is unique in comparison to the broader literature. We attempt to implement theoretically relevant variables that apply to our study, 
and follow the approaches of previous research where appropriate. We view our study as being a flagship study in the determinants of voting for port infrastructure which will open paths for future research in understanding public preferences for port projects.

\subsection{Rhode Island 2016 General Election and Census Data}

The Rhode Island State Department's Board of Elections provided the voting results from the 2016 general election. These data include the number of votes for each individual running for office and the number of votes cast for and against each ballot question for all 419 state voting precincts.

Demographic and socioeconomic data for Rhode Island are obtained from the 2017 American Community Survey (ACS). The U.S. Census Bureau calculates these data based on 5year rolling averages and are collected at the block group level-the smallest geographic scale for publicly available data. Rhode Island contains 815 block groups with an average of around 1,300 people per block group. We collect data on median age, median per capita income, population, and proportion of homeowners. Additionally, percentage of the population falling into various categories of race, ethnicity, sex, educational attainment, and employment by industry are collected.

Due to the disparity in observation level between the polling data and census data, all block group census data is aggregated to the precinct level for the Rhode Island analysis. To accomplish this, we use GIS to overlay the voting precinct and block group shapefiles. We then calculate the proportions of each block group that lies within a voting precinct. Using these proportions, we aggregate the block group data to the precinct level. Three precincts were dropped due to missing 
information in either the census or polling data and the final sample for our Rhode Island model comprises 416 precincts.

Additional GIS work was required for our analysis and data collection. We acquired measures of area for each precinct and block group in our sample, which we use to calculate our estimate of population density. We use GIS to identify which precincts are along the coast as well as the latitude and longitude coordinates for the two ports, Providence and Davisville at Quonset. We use these port coordinates to calculate Euclidean distance between the precinct centroids and ports in GIS.

Figure 1 maps each precinct's approval for the port infrastructure bonds measure, and patterns of support are visible. For many precincts close to Providence Port we see a very high approval percentage. Similarly, some of the western island precincts show high support. There are several precincts to the northwest that exhibit lower support levels, which might be due to the rural nature and increased distance from the ports. The precinct with the lowest support approval was only 49\%, indicating a level of consistency amongst precincts in Rhode Island.

\subsection{Regression Model}

We use a weighted least squares (WLS) regression model to examine the support for Rhode Island's port infrastructure bond. Following Deacon and Shapiro (1975), we regress the percent of 'yes' votes for the port infrastructure bond on a suite of demographic, and locational controls weighted by the number of votes from the precinct. Our model is presented as

(1) $\%$ Port Approval $_{i}=\alpha+\beta$ Democratic Vote Share $_{i}+$ Socioeconomic $_{\boldsymbol{i}} \boldsymbol{\gamma}$ + Neighborhood $_{i} \delta+$ Industry $_{i} \vartheta+\varepsilon_{i}$ 
where our dependent variable is \% Port Approval, , which is the percent of 'yes' votes for the port infrastructure ballot measure for precinct $i$. Democratic Vote Share Vis $_{i}$ defined as the percent of Democratic votes as a portion of total votes in the presidential contest. While ports are not a partisan issue and thus we have no reason to believe Democrats support ports more than Republicans or vice versa, we do believe that Democrats have higher support for public spending in general and thus we expect Democratic Vote Share V $_{i}$ to be a strong positive predictor of approval.

Socioeconomic $_{\boldsymbol{i}}$ is a vector of socioeconomic variables that include measures of age,

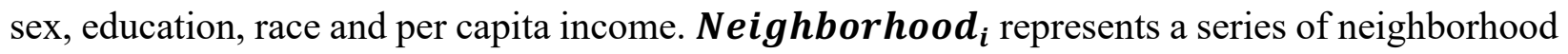
variables such as the percentage of homeowners, an identifier variable for precincts that reside on the coast, and a precinct's population density. Different papers have indicated that population density is a factor in the support of various environmental referendum so we include the population density of a precinct in our model (Altonji et al. 2016).

Additionally, we include a measure of a precinct's distance to the nearest port. Proximity to a port will likely be a determinant of support due to the direct economic impacts from port activity within the vicinity. We model the effect of miles to the nearest port with a piecewise linear function in which the effect of proximity on port approval for precincts decreases as distance increases. In our model we assume there is no effect for distances beyond eight miles and constrain our function this way. ${ }^{2}$

\footnotetext{
${ }^{2}$ We estimated a model similar to Eq. (1), but excluding port distance, and plotted the residuals against the distance variable in an effort to accurately assess the relationship between \% Port Approval and Distance to the Nearest Port. Using an unconstrained linear or quadratic function for modeling would not be appropriate due to our prediction process later on. By adopting a constrained piecewise linear function, we also ensure that our predicted estimates are not severely impacted by large distance observations in other states compared to Rhode Island's distance values.
} 
Industry $y_{i}$, is a vector of job sector variables including the percentage of construction, manufacturing, transportation, warehousing, agriculture and resource management jobs. Both previous literature and intuition suggest that jobs related or semi-related to industries that utilize ports for business may be a factor in port infrastructure approval (Kahn \& Matsusaka 1997). We also posit that it is more likely that individuals in these fields have a higher awareness of the ports within Rhode Island and the presence of these industries may affect the port infrastructure bonds' passage.

Observations are weighted by the number of total port infrastructure votes in a precinct. Ultimately, we are interested in individual behavior, and precincts with more votes are more informative about how individuals vote. An observed precinct with 1,000 voters gets ten times as much weight than a precinct with 100 voters.

\subsection{Prediction Application}

As an extension of our voting model, we use the regression estimates obtained from Eq. (1) to project votes for a hypothetical port infrastructure bond in other states based on their political and socioeconomic attributes. Our prediction group comprises all contiguous U.S. states that have ports, including the Great Lakes states.

Because we are not only interested in understanding voting preferences in Rhode Island but also in predicting public support for port infrastructure spending in other states, we acquired the same census variables, from the 2017 ACS, at the block group level, for 28 states. Similarly, we gather latitude and longitude coordinates, and area measures in GIS at the block group level.

2016 presidential vote data for our prediction model are obtained from a GitHub data repository at the county level. It would be better to have presidential vote at the block group level, 
however that data does not exist. Thus, we assign each block group within a county to that county's Democratic vote share.

We construct a comparable measure of a block group's distance to the nearest port using the World Port Index (WPI). ${ }^{3}$ This database comprises thousands of ports indexed and coded by the National Geospatial-Intelligence Agency. They provide a comprehensive list of all ports included in our sample states including coordinates, measurements of harbor size, and capacity.

Using the estimated coefficients from Eq. (1), we predict port infrastructure approval using Eq. (2):

(2) $\%$ Port Approval $_{i s}=\hat{\alpha}+\hat{\beta}$ Democratic Vote Share $_{i s}+$ Socioeconomic $_{i s} \widehat{\gamma}$ + Neighborhood $_{i s} \widehat{\delta}+$ Industry $_{i s} \widehat{\vartheta}$

The values for our dependent variable, \% Por $\widehat{\operatorname{App}} \mathrm{rroval}_{i s}$, are calculated using a linear function based on the estimated coefficients from Eq. (1) and independent variables from the presidential voting and census data from other states. These data are at the $i$ th block group level for the $s$ state. To obtain the overall state voting results, the dependent variable \% Por $\widehat{\text { Approval }}$ is is multiplied by the voting population for each block group, then summed to the state level, then divided by the total number of votes to get the predicted percentage approval statewide.

\section{Results}

\footnotetext{
${ }^{3}$ The World Port Index does not have a state identifier in the data. We joined the port points to specific states using shapefiles in GIS, and assume that ports are correctly matched to their correct state.
} 


\subsection{Regression Results}

Table 2 presents the results from our WLS model. Our model includes several control variables that are statistically significant and the R-squared indicates that around $73 \%$ of the variation in the percent of port approval is explained by our independent variables.

The coefficient on Democratic Vote Share is positive and statistically significant. The results suggest that a 1 percentage point increase in the Democratic Vote Share of a precinct is associated with a 0.19 percentage point increase in port approval. Conforming to previous literature, political affiliation here is one of the largest drivers of support for this bond measure (Kahn and Matsusaka 1997, Altonji et al. 2016). This result suggests that port infrastructure is a strongly partisan issue, but we examine this in greater details in the following section.

The coefficient on $\%$ Homeowner (the percentage of homeowners (as opposed to renters) within a precinct) is negative and statistically significant. This coefficient suggests that a 1 percentage point increase in the percentage of homeowners is associated with a 0.05 percentage point decrease in port approval. These results may indicate that homeowners may be more hesitant to support the allocation of funds to port infrastructure compared to renters. This "renter effect" is consistent with previous literature that suggests homeowners are less likely to support public spending than renters (Oates 2005, Prendergast et al. 2019).

Our results suggest that Black and Hispanic communities value public spending on port infrastructure more than white communities. Similarly, Black and Hispanic communities have been shown to support public spending on environmental measures. Previous research suggests that this may have to do with the prevalence of environmental degradation in minority communities (Kahn 2002). In this case, however, another explanation is that a large proportion of minority communities are located close to the Providence Port. While we control for a precinct's 
distance to the nearest port, these communities with a higher minority population may be more aware of the port's impact on the local economy and may support port infrastructure spending due to their perception of potential benefits to their neighborhoods.

We find evidence that median per capita income positively impacts port infrastructure approval. A $\$ 1000$ increase in a precinct's median per capita income, on average increases the percent of port approval by 0.03 percentage points. This suggests that as an individual's income increases they are more willing to pay for port infrastructure. However, we note that bonds are paid by general revenue so the burden of payment impacts higher income voters more than lower income voters. Regardless, the results show that higher income areas are still willing to support the measure. Previous literature identifies a multitude of income effects on voter support for public spending and our results conform accordingly (Kahn \& Matsusaka 1997, Wu \& Cutter 2011).

We also account for a precinct's distance to the nearest port, suggesting that the closer a precinct is to a port the more aware that precinct is of the port's impacts on the economy and community. We find that for precincts within eight miles of a port, a one-mile increase in distance from the nearest port decreases the percentage of port approval by 0.30 percentage points all else equal. Intuitively this makes sense. In general, a precinct that is further inland is unlikely to be as invested in improving the infrastructure of a state port compared to a more coastal precinct.

Several variables were found to have no statistically significant impact on the percent of port approval. We find that college education is not a predictor of approval. While prior literature has found that education is positively related to environmental voting, research has also found education to have an insignificant or even negative effect in non-environmental measures (Wu \& Cutter 2011, Kahn 2002). Similarly, we find no effect for age, the percentage of females, our coastal identifier, or the population density of a precinct. 
Intuition would suggest that the transportation, warehousing and utility industry jobs would be an important factor in port approval due to the fact that Providence Port employs many people in these fields (Poole et al. 2015). However, we find that the only statistically significant industry impacting port approval is the construction industry. Our results suggest that the percentage of people employed in the construction field within a precinct negatively impacts port approval. The magnitude and significance of this variable may be due to spurious correlation with other variables or some unobservable relationship we are not accounting for.

\subsection{Partisanship in Ballot Measures}

The regression results from Table 2 portray the support of port infrastructure as a heavily partisan issue, which is consistent with previous findings on voting for public goods. However, we compare the results of the port bond issue with other bond issues on the same 2016 general election ballot to explore the degree of partisan support for ports relative to other public goods on the ballot. The other three bonds are: 1) Green Economy, which funds a suite of environmental improvements; 2) Housing Opportunity, which funds affordable housing and blight remediation; and, 3) Higher Education, which funds the state's colleges and universities. ${ }^{4}$

Figure 2 presents four panels, with each plotting the percent approval against the Democratic vote share by precinct for each of the bond referendums on the ballot. Across all plots, we see strong positive linear relationships between approval and Democratic vote share. In general, as the percentage of Democratic vote share increases within a precinct the higher approval is likely to be for these issues. However, the slope of the port infrastructure bond plot is flatter than the

\footnotetext{
${ }^{4}$ Pearson-Merkowitz and Lang (2019) examine individual voting determinants on Green Economy Bonds and Affordable Housing Bonds using exit poll data. Their findings mirror the findings here that Democrats are more likely to support both bonds than Republicans, with a larger gap of support for affordable housing.
} 
others, indicating port infrastructure is the least partisan issue of the four. Additionally, the port infrastructure bond approval is always above $49 \%$, which is not true for other bond measures. This shows that while support for port infrastructure is correlated with Democratic voting, it is much less so in comparison. On average, the gap of support between Republicans and Democrats is smaller for port infrastructure relative to the other bond issues that appeared on the ballot.

A portion of the observed slope for port infrastructure bonds can likely be attributed to Democrat's willingness to be taxed for public goods regardless of the specific good, and their willingness to expand government. If it were not for this baseline difference, port infrastructure spending may even be equally preferred across political parties.

\subsection{Prediction Results}

The second objective for this study was to use our regression results to predict how other coastal and Great Lakes states might vote on a hypothetical port infrastructure bond issue. We use the results from Eq. (1) and our collected census data to predict the outcome of a hypothetical ballot for each state in our sample.

Every state for which we project votes is predicted to pass their hypothetical referendum. Despite the differences across states in politics and population characteristics, all states are expected to authorize public spending for port infrastructure. Further, the predicted approval ranges from a low of $58.49 \%$ in Alabama to $65.40 \%$ in California. Thus, even the state with the least support would be expected to pass a port infrastructure bond referendum by a large margin. Given the state divides observed on many issues (i.e. health care, immigration, climate change), we see this as important, and argue that the port industry could harness this broad public support for major infusions of capital. 
In Table 3 we examine the percentage of predicted approval for a port infrastructure bond and some mean characteristics of sample states to get a sense of how approval varies by state. ${ }^{5} \mathrm{In}$ Column 3 we note that Mississippi has passed the hypothetical port infrastructure ballot with a predicted approval of 59.47\%. Mississippi has a lower average Democratic vote share, and median per capita income than Rhode Island, but a larger homeowner population and more Black and Hispanic communities similar to Texas.

In comparison, Column (2) presents the results from New York. New York passed with a predicted approval rate of $64.03 \%$. The state has a higher Democratic vote share and a more prevalent Black and Hispanic community than Rhode Island, but holds comparable college education rate.

Figure 3 maps the percent of approval in which a state would pass a hypothetical ballot for port infrastructure. We can see that the states with the highest percent of predicted approval are in the Northeast, the West Coast and parts of the Great Lakes area. In contrast, states with lower predicted approval tend to be in the South. These differences likely have to do with how similar a state's characteristics are to Rhode Island. For example, the more Republican leaning a state is, then the lower the support is predicted to be for public port financing because of the higher Democratic vote share in the state of Rhode Island. Regardless of these differences, we see that the support for port development and infrastructure is fairly consistent across states.

To assure that some error in using Rhode Island for our projection doesn't automatically pass every measure, we choose to run a different prediction model on the affordable housing bond measure. Using the same control variables for all states within our sample we calculate linear predictions for the outcome of a hypothetical affordable housing bond measure. We find that

\footnotetext{
${ }^{5}$ See the online appendix for these statistics and analysis for all 23 states.
} 
several states would be expected to fail an affordable housing bond. As evidence by Figure 2, affordable housing is much more a partisan issue than ports, and as a result many southern and midwestern states are predicted to reject such a measure.

\subsection{Limitations of Rhode Island as Proxy, Aggregate Data and Prediction Model}

As stated previously, Rhode Island is more likely than other states to hold bond issues, is more Democratic leaning, and is the smallest state in the U.S., all of which may affect the projections of votes to larger, more heterogenous states. We have attempted to control for as many of these differences as possible through our multiple regression model.

A common problem within the voting literature is the use of aggregate data when attempting to identify individual voting preferences. When using aggregate data to infer individual decisions aggregation bias may occur, and the actual relationship of individual preferences for port infrastructure could be different than the aggregate relationship. The size and heterogeneity of the geographic unit in which the data are aggregated affects the magnitude of the aggregation bias, and the smaller the geographic unit the better (Wu \& Cutter 2011). Precincts are the smallest unit possible, but of course individual data would be idea. However, due to ballot confidentiality this is the only way to study the real consequences of voting decisions.

We rely on the results of our voting model Eq. (1) for our prediction application. The predictions are made using the other states' demographic and socioeconomic characteristics. We recognize the limitations of this application, primarily that we do not know how another state would frame a similar port infrastructure bond issue or choose how to allocate funds to different ports or projects. The particular impacts of dissimilar locations, natural conditions, and port project details may result in a different outcome than the results that we report. 


\section{Conclusion}

Ports are facing pervasive challenges including structure deterioration and growing adaptation needs for rising business demands and climate driven sea level rise. As these concerns worsen the need for infrastructure and development funding becomes an even more pressing issue.

The purpose of this paper is to provide an empirical study measuring the determinants of voting behavior on port infrastructure bonds. We exploit a comprehensive data set compiled from the Rhode Island Board of Elections and the 2017 American Community Survey. We employ a statewide analysis of a port infrastructure bond in Rhode Island and use these results to predict hypothetical port bond measures in other states.

Our results provide new insights into what types of people and communities support public spending on port infrastructure. We find strong evidence that public spending on ports is more of a bipartisan issue compared to other public financing efforts like affordable housing or green economy bonds. Additionally, neighborhoods with a larger minority presence and those with higher median per capita income are more likely to support port development. While areas with a higher homeowner population and those communities farther from coastal areas where ports are located may be less likely to support port spending. Further, our prediction model finds that all coastal and Great Lakes states would pass a hypothetical port bond issue if they were to hold one. We see that the support for port development and infrastructure is fairly consistent across states despite demographic and socioeconomic differences, making bond issues a viable option for the port industry to secure financing. 
This is a topic that has been largely unexplored and we consider this research a foundational step in establishing preferences for port projects. Explicitly verifying public perception of port projects and port industries holds import implications for future bond measures and opportunities for additional research. Future research might incorporate an exit poll survey to determine how individual voting preferences vary compared to the aggregate voting data publicly available. Alternatively, interviewing maritime organizations, businesses and industry stakeholders to better understand the processes behind public bond issues and securing funding opportunities would lead to additional insights within the literature.

\section{Acknowledgments}

Many thanks to Joseph Riccio and John Riendeau from the Rhode Island Commerce Corporation for input on this study. 


\section{References}

Altonji, Matthew, Corey Lang, and Gavino Puggioni. "Can Urban Areas Help Sustain the Preservation of Open Space? Evidence from Statewide Referenda." Ecological Economics 130 (October 2016): 82-91. https://doi.org/10.1016/j.ecolecon.2016.06.026.

American Association of Port Authorities. 2015. Port Surface Transportation Infrastructure Survey: The State of Freight.

American Society of Civil Engineers. 2017. 2017 Infrastructure Report Card: Ports. edited by Economic Development Research Group. Washington, D.C.

Anderson, Patrick. "R.I. Targets for Receivership Land Considered for Port of Providence

Expansion.” The Providence Journal, 25 June 2016, https://www.providencejournal.com/news/20160624/ri-targets-for-receivership-landconsidered-for-port-of-providence-expansion.

Baird, A.J. (2004) Public goods and the public financing of European seaports. Maritime Policy \& Management 31, 375-391.

Becker, Austin H., Michele Acciaro, Regina Asariotis, Edgard Cabrera, Laurent Cretegny, Philippe Crist, Miguel Esteban, Andrew Mather, Steve Messner, Susumu Naruse, Adolf K. Y. Ng, Stefan Rahmstorf, Michael Savonis, Dong-Wook Song, Vladimir Stenek, and Adonis F. Velegrakis. 2013. "A note on climate change adaptation for seaports: a challenge for global ports, a challenge for global society." Climatic Change 120 (4):683-695. doi: 10.1007/s10584-013-0843-z.

Becker, Austin, and Eric Kretsch. 2019. "The Leadership Void for Climate Adaptation Planning: Case Study of the Port of Providence (Rhode Island, United States)." Frontiers in Earth Science 7. doi: 10.3389/feart.2019.00029. 
"Bond Issues." Ballotpedia, https://ballotpedia.org/Bond issues on the ballot\#By year Accessed May 2019.

Brunner, Eric, and Jon Sonstelie. "Homeowners, property values, and the political economy of the school voucher." Journal of Urban Economics 54.2 (2003): 239-257.

Carini, Frank. "Top Lawmakers Ignore Waterfront Environmental Concerns.” EcoRI News, EcoRI News, 17 Aug. 2016, https://www.ecori.org/smart-growth/2016/8/13/waterfrontenvironmental-concerns-dont-register-with-top-lawmakers.

Deacon, Robert, and Perry Shapiro. "Private preference for collective goods revealed through voting on referenda." The American Economic Review 65.5 (1975): 943-955.

Government Accountabiity Office. 2012. MARITIME INFRASTRUCTURE Opportunities Exist to Improve the Effectiveness of Federal Efforts to Support the Marine Transportation System. In GAO-13-80 Report to Congress. Washington, DC.

Heintzelman, Martin D., Patrick J. Walsh, and Dustin J. Grzeskowiak. "Explaining the Appearance and Success of Open Space Referenda." Ecological Economics 95 (November 2013): 108-17. https://doi.org/10.1016/j.ecolecon.2013.08.001.

Kahn, Matthew E. "Demographic Change and the Demand for Environmental Regulation." Journal of Policy Analysis and Management 21, no. 1 (2002): 45. https://doi.org/10.1002/pam.1039.

Kahn, Matthew E., and John G. Matsusaka. "Demand for Environmental Goods: Evidence from Voting Patterns on California Initiatives." The Journal of Law and Economics 40, no. 1 (April 1997): 137-74. https://doi.org/10.1086/467369. 
Kotchen, Matthew J., and Shawn M. Powers. "Explaining the Appearance and Success of Voter Referenda for Open-Space Conservation.” Journal of Environmental Economics and Management 52, no. 1 (July 2006): 373-90. https://doi.org/10.1016/j.jeem.2006.02.003.

Matsa, D. A., \& Miller, A. R. (2019). Who Votes for Medicaid Expansion? Lessons from Maine's 2017 Referendum. Journal of health politics, policy and law, 44(4), 563-588.

Matsusaka, John G. "Direct democracy works." Journal of Economic perspectives 19.2 (2005): 185-206.

Munro, J., Pearce. J., Brown, G., Kobryn, H., Moore, S.A. (2017) Identifying 'public values' for marine and coastal planning: Are non-residents really so different?” Ocean \& Coastal Management 148, 9-21

Nelson, Erik, Michinori Uwasu, and Stephen Polasky. "Voting on Open Space: What Explains the Appearance and Support of Municipal-Level Open Space Conservation Referenda in the United States?” Ecological Economics 62, no. 3-4 (May 2007): 580-93. https://doi.org/10.1016/j.ecolecon.2006.07.027.

Oates, Wallace E. "Toward a second-generation theory of fiscal federalism." International tax and public finance 12.4 (2005): 349-373.

Pearson-Merkowitz, S., \& Lang, C. (2019). Smart Growth at the Ballot Box: Understanding Voting on Affordable Housing and Land Management Referendums. Urban Affairs Review, 1078087419861430.

Poole, T., Good, K. 4Ward Planning Inc., “The Economic Impact of ProvPort's Terminal Services." 2015. Economic and Real Estate Analysis for Sustainable Land Use Outcomes. (Jan 2015): 2-45. 
Prendergast, P., Pearson-Merkowitz, S., \& Lang, C. (2019). "The individual determinants of support for open space bond referendums." Land Use Policy, 82, 258-268.

Raimondo, G. 2016. "Time to invest in continued success at Rhode Island's ports - by Governor Gina Raimondo." New England Real Estate Journal, Oct. 14, 2016. http://nerej.com/time-toinvest-in-continued-success-at-rhode-islands-ports-by-governor-gina-raimondo.

Theil, H., 1971. The Principles of Econometrics. John Wiley \& Sons.

U.S. Department of Transportation, Bureau of Transportation Statistics. 2018. Port Performance Freight Statistics Annual Report to Congress 2018 Washington, DC.

Vining, A.R., Boardman, A.E. (2008) The potential role of public-private partnerships in the upgrade of port infrastructure: normative and positive considerations. Maritime Policy \& Management 35, 551-569.

Wu, Xiaoyu, and Bowman Cutter. "Who Votes for Public Environmental Goods in California?" Ecological Economics 70, no. 3 (January 2011): 554-63.

https://doi.org/10.1016/j.ecolecon.2010.10.008. 


\section{Tables and Figures}

Table 1: Rhode Island Descriptive Statistics

\begin{tabular}{|c|c|}
\hline Port Infrastructure Approval (\%) & $\begin{array}{l}63.26 \\
(5.13)\end{array}$ \\
\hline Democratic Vote Share (\%) & $\begin{array}{l}57.89 \\
(14.28)\end{array}$ \\
\hline Median Age & $\begin{array}{l}43.51 \\
(6.63)\end{array}$ \\
\hline Median Per Capita Income (000’s) & $\begin{array}{l}37.97 \\
(13.57)\end{array}$ \\
\hline Homeowner $(\%)$ & $\begin{array}{l}67.33 \\
(20.85)\end{array}$ \\
\hline Black or Hispanic $(\%)$ & $\begin{array}{l}14.84 \\
(21.04)\end{array}$ \\
\hline Female $(\%)$ & $\begin{array}{l}51.54 \\
(3.25)\end{array}$ \\
\hline College Education $(\%)$ & $\begin{array}{l}38.42 \\
(10.91)\end{array}$ \\
\hline Distance to Nearest Port (w/n $8 \mathrm{mi}$.) & $\begin{array}{l}8.26 \\
(5.34)\end{array}$ \\
\hline Population Density $\left(\mathrm{pop} / \mathrm{mi}^{2}\right) / 1000$ & $\begin{array}{l}3.85 \\
(4.42)\end{array}$ \\
\hline Manufacturing Jobs (\%) & $\begin{array}{l}5.25 \\
(2.07)\end{array}$ \\
\hline Transportation, Warehousing, and Utility Jobs (\%) & $\begin{array}{l}1.82 \\
(1.06)\end{array}$ \\
\hline Natural Resource Jobs (\%) & $\begin{array}{l}0.24 \\
(0.44)\end{array}$ \\
\hline Construction Jobs (\%) & $\begin{array}{l}2.76 \\
(1.62)\end{array}$ \\
\hline Observations & 416 \\
\hline Total Population & $1,005,103$ \\
\hline
\end{tabular}

Note: Table reports the means with standard deviation in parentheses. Observations are at the precinct level and weighted by total votes for port infrastructure. 
Table 2: Rhode Island Port Ballot Regression Results

\begin{tabular}{|c|c|}
\hline $\begin{array}{l}\text { Dependent Variable: \% Port Approval } \\
\text { Independent Variables }\end{array}$ & \\
\hline \multirow[t]{2}{*}{ Democratic Vote Share (\%) } & 0.19 \\
\hline & $(0.02)^{* * *}$ \\
\hline \multirow[t]{2}{*}{ Median Age } & 0.00 \\
\hline & $(0.03)$ \\
\hline \multirow[t]{2}{*}{ Median Per Capita Income (000’s) } & 0.03 \\
\hline & $(0.01)^{* *}$ \\
\hline \multirow[t]{2}{*}{ Homeowner $(\%)$} & -0.05 \\
\hline & $(0.01)^{* * *}$ \\
\hline \multirow[t]{2}{*}{ Black or Hispanic $(\%)$} & 0.04 \\
\hline & $(0.02)^{* * *}$ \\
\hline \multirow[t]{2}{*}{ Female $(\%)$} & 0.03 \\
\hline & $(0.04)$ \\
\hline \multirow[t]{2}{*}{ College Education (\%) } & 0.03 \\
\hline & $(0.03)$ \\
\hline \multirow[t]{2}{*}{ Distance to Nearest Port (w/n $8 \mathrm{mi}$.) } & -0.30 \\
\hline & $(0.09)^{* * *}$ \\
\hline \multirow[t]{2}{*}{ Coastal Precinct $(1=y e s)$} & -0.29 \\
\hline & $(0.41)$ \\
\hline \multirow[t]{2}{*}{ Population Density (pop/miles $\left.{ }^{2}\right) / 100$} & -0.03 \\
\hline & $(0.06)$ \\
\hline \multirow[t]{2}{*}{ Manufacturing Jobs (\%) } & 0.01 \\
\hline & $(0.07)$ \\
\hline \multirow[t]{2}{*}{ Transportation, Warehousing, or Utility Jobs (\%) } & 0.09 \\
\hline & $(0.13)$ \\
\hline \multirow[t]{2}{*}{ Natural Resource Jobs (\%) } & -0.34 \\
\hline & $(0.38)$ \\
\hline \multirow[t]{2}{*}{ Construction Jobs (\%) } & -0.28 \\
\hline & $(0.10)^{* * *}$ \\
\hline \multirow[t]{2}{*}{ Constant } & 54.33 \\
\hline & $(3.32)^{* * *}$ \\
\hline Observations & 416 \\
\hline R-squared & 0.73 \\
\hline
\end{tabular}

Note: OLS regression model weighted by the total number of port ballot votes.

$\%$ College Education includes bachelors and advanced degrees. Population Density is equal to the population divided by square miles all over 1000 .

Natural Resource Jobs include agriculture, fishing, forestry, oil and natural gas related jobs. Observations are at the precinct level. Robust standard errors in parentheses. $* * * \mathrm{p}<0.01, * * \mathrm{p}<0.05, * \mathrm{p}<0.1$ 
Table 3: Prediction Results for Sample States

\begin{tabular}{|c|c|c|c|c|c|c|}
\hline & (1) & $(2)$ & (3) & (4) & $(5)$ & (6) \\
\hline States: & Rhode Island & New York & Texas & Mississippi & Minnesota & Alabama \\
\hline \multicolumn{7}{|l|}{ A. Prediction Results } \\
\hline$\%$ Port Approval & $63.83 \%$ & $64.02 \%$ & $60.79 \%$ & $59.48 \%$ & $60.53 \%$ & $58.49 \%$ \\
\hline \multicolumn{7}{|l|}{ B. Summary Statistics } \\
\hline \multirow[t]{2}{*}{ Democratic Vote Share (\%) } & 58.67 & 62.82 & 45.42 & 42.48 & 50.70 & 36.39 \\
\hline & $(4.21)$ & $(18.66)$ & $(18.01)$ & (18.17) & (15.59) & $(16.87)$ \\
\hline \multirow[t]{2}{*}{ Median Age } & 41.30 & 39.52 & 36.91 & 38.79 & 40.27 & 40.41 \\
\hline & $(16.87)$ & $(10.13)$ & $(9.22)$ & $(8.99)$ & $(8.65)$ & $(8.80)$ \\
\hline \multirow[t]{2}{*}{ Median Per Cap. Income } & 33.67 & 35.73 & 28.62 & 21.70 & 34.19 & 24.34 \\
\hline & $(16.51)$ & $(25.54)$ & $(18.50)$ & $(9.73)$ & (14.30) & (11.61) \\
\hline \multirow[t]{2}{*}{ Homeowner (\%) } & 59.76 & 56.15 & 62.81 & 66.95 & 72.87 & 67.62 \\
\hline & $(27.03)$ & $(31.50)$ & $(26.36)$ & $(22.37)$ & $(23.63)$ & $(22.42)$ \\
\hline \multirow[t]{2}{*}{ Female $(\%)$} & 51.57 & 51.54 & 50.41 & 51.87 & 50.10 & 51.74 \\
\hline & $(6.20)$ & $(6.89)$ & $(6.81)$ & $(7.35)$ & $(5.37)$ & $(6.68)$ \\
\hline \multirow[t]{2}{*}{ Black or Hispanic $(\%)$} & 21.29 & 32.85 & 50.37 & 44.34 & 10.91 & 34.85 \\
\hline & $(27.03)$ & $(34.76)$ & $(31.61)$ & $(31.60)$ & $(15.01)$ & $(32.24)$ \\
\hline \multirow[t]{2}{*}{ College Education (\%) } & 23.66 & 24.68 & 17.52 & 13.28 & 22.88 & 14.91 \\
\hline & $(15.32)$ & (16.69) & $(15.44)$ & (10.18) & (13.84) & $(12.32)$ \\
\hline \multirow[t]{2}{*}{ Distance to Nearest Port (mi.) } & 6.54 & 15.53 & 176.20 & 162.01 & 145.59 & 189.11 \\
\hline & $(5.54)$ & $(20.00)$ & $(147.74)$ & $(92.14)$ & $(48.80)$ & $(81.68)$ \\
\hline Observations & 814 & 15,402 & 15,800 & 2,161 & 4,109 & 3,437 \\
\hline
\end{tabular}

Note: Observations at the block group level. Under summary statistics we report the means with standard deviations in parentheses. The Rhode Island means at the block group level may differ from the means at the precinct level due to the calculation of proportions, aggregation to the precinct level, and weights. 
Figure 1: Rhode Island Port Infrastructure Bond Approval by Precinct

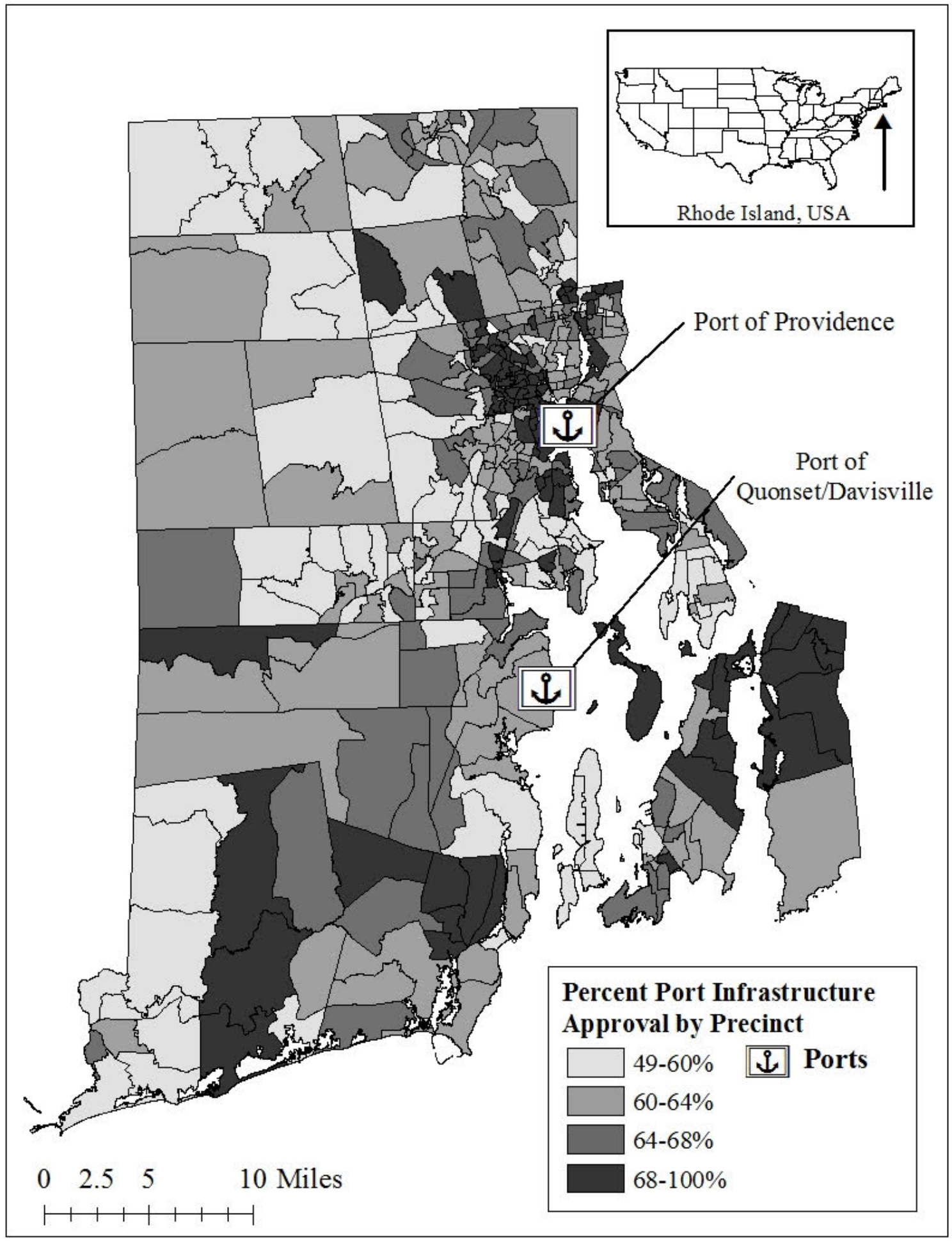


Figure 2: Ballot Measure Approval by Democratic Vote Share
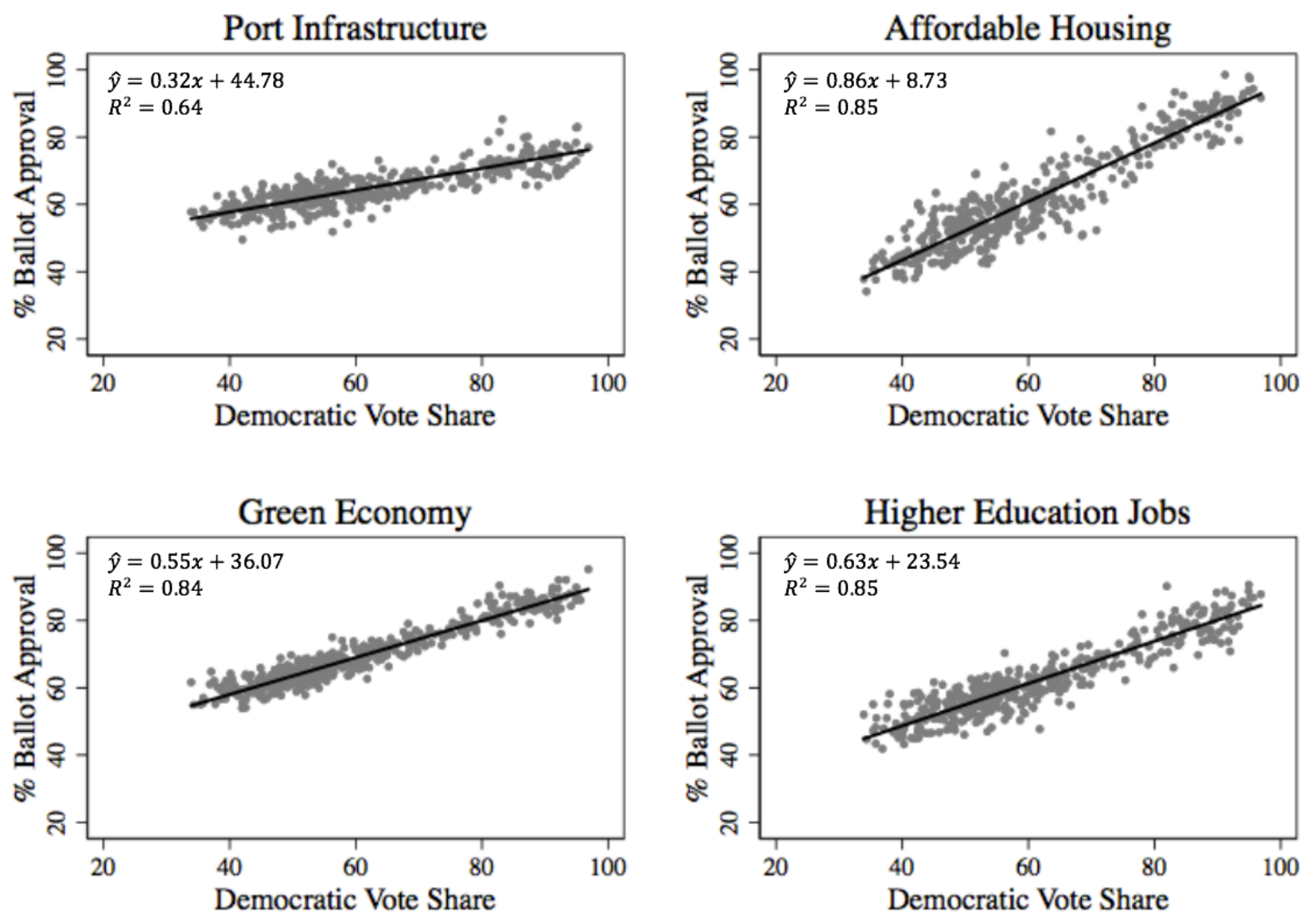
Figure 3: Map of States' Predicted Percent Approval for Port Infrastructure Ballot

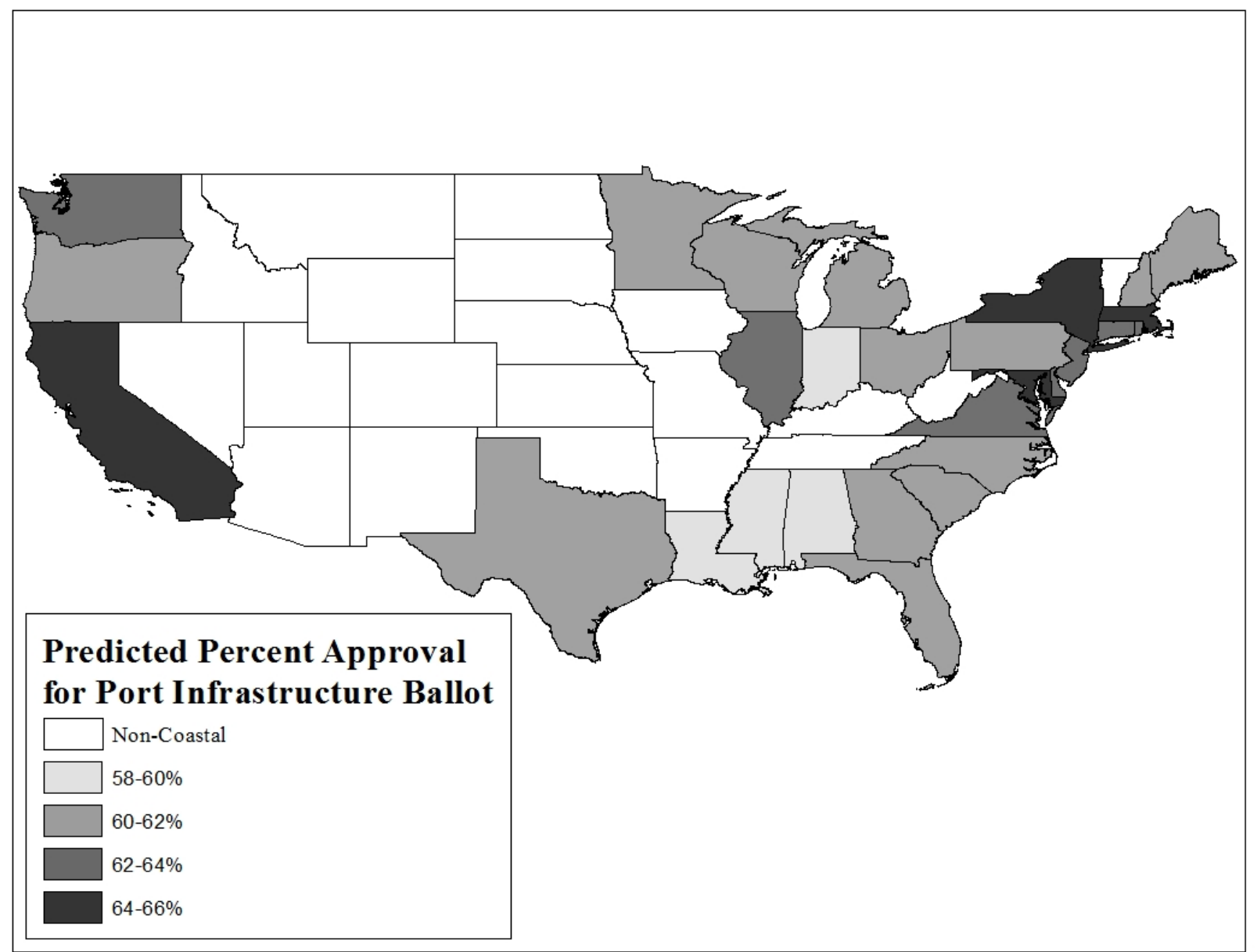

Note: Census data, matching that of model 1, was collected on all observed states from the 2017 American Community Survey at the block group level. The Rhode Island WLS regression model was run, and then predictions were calculated by state for the percent approval for a hypothetical port infrastructure ballot. Predictions are based on the demographics and other variables from our model. 
Table A1: Summary Statistics

\begin{tabular}{|c|c|c|c|c|c|c|}
\hline & (1) & (2) & (3) & (4) & 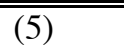 & (6) \\
\hline States: & Maine & California & Connecticut & Delaware & Florida & Georgia \\
\hline \multicolumn{7}{|l|}{ A. Prediction Results } \\
\hline$\%$ Port Approval & $60.02 \%$ & $65.05 \%$ & $63.11 \%$ & $62.46 \%$ & $61.28 \%$ & $60.98 \%$ \\
\hline \multicolumn{7}{|l|}{ B. Summary Statistics } \\
\hline \multirow[t]{2}{*}{ Democratic Vote Share (\%) } & 50.26 & 65.59 & 57.11 & 57.03 & 49.74 & 47.19 \\
\hline & $(4.45)$ & $(13.04)$ & $(5.04)$ & $(11.74)$ & $(12.99)$ & $(20.93)$ \\
\hline \multirow[t]{2}{*}{ Median Age } & 43.57 & 38.50 & 41.93 & 42.07 & 44.13 & 38.33 \\
\hline & $(8.74)$ & $(9.48)$ & $(8.90)$ & $(11.08)$ & $(12.44)$ & $(8.69)$ \\
\hline \multirow[t]{2}{*}{ Median Per Cap. Income } & 36.24 & 34.86 & 41.84 & 34.19 & 30.16 & 27.17 \\
\hline & $(12.68)$ & $(22.40)$ & $(23.53)$ & $(19.31)$ & (19.16) & $(15.69)$ \\
\hline \multirow[t]{2}{*}{ Homeowner $(\%)$} & 70.33 & 55.82 & 66.79 & 71.66 & 64.71 & 61.82 \\
\hline & $(24.37)$ & $(26.93)$ & $(28.26)$ & $(23.67)$ & $(24.76)$ & $(25.28)$ \\
\hline \multirow[t]{2}{*}{ Female $(\%)$} & 50.72 & 50.48 & 51.39 & 51.84 & 51.18 & 51.50 \\
\hline & $(5.50)$ & $(6.13)$ & $(6.02)$ & $(6.23)$ & $(6.85)$ & $(7.07)$ \\
\hline \multirow[t]{2}{*}{ Black or Hispanic $(\%)$} & 4.88 & 42.39 & 26.32 & 30.37 & 38.21 & 41.35 \\
\hline & $(8.45)$ & $(29.90)$ & $(29.15)$ & $(26.74)$ & $(31.62)$ & $(31.00)$ \\
\hline \multirow[t]{2}{*}{ College Education (\%) } & 24.93 & 23.04 & 26.82 & 22.58 & 20.89 & 18.62 \\
\hline & (12.09) & $(17.28)$ & $(15.44)$ & $(15.52)$ & $(14.45)$ & $(15.02)$ \\
\hline \multirow[t]{2}{*}{ Distance to Nearest Port (mi.) } & 46.01 & 25.94 & 18.21 & 24.91 & 23.67 & 184.27 \\
\hline & $(25.30)$ & (28.74) & $(13.42)$ & $(28.43)$ & (19.43) & $(72.68)$ \\
\hline Observations & 921 & 23,196 & 2,582 & 573 & 11,409 & 5,530 \\
\hline
\end{tabular}

Note: Observations at the block group level. Under summary statistics we report the means with standard deviations in parentheses. 
Table A2: Summary Statistics

\begin{tabular}{|c|c|c|c|c|c|c|}
\hline & (1) & (2) & (3) & (4) & (5) & (6) \\
\hline States: & Illinois & Indiana & Michigan & Maryland & Massachusetts & New Hampshire \\
\hline \multicolumn{7}{|l|}{ A. Prediction Results } \\
\hline$\%$ Port Approval & $62.88 \%$ & $58.21 \%$ & $60.49 \%$ & $64.28 \%$ & $64.38 \%$ & $59.99 \%$ \\
\hline \multicolumn{7}{|l|}{ B. Summary Statistics } \\
\hline \multirow[t]{2}{*}{ Democratic Vote Share (\%) } & 58.25 & 39.38 & 50.89 & 65.43 & 65.19 & 50.27 \\
\hline & $(18.78)$ & $(14.78)$ & $(13.66)$ & $(21.39)$ & $(9.15)$ & $(4.46)$ \\
\hline \multirow[t]{2}{*}{ Median Age } & 39.63 & 39.52 & 40.83 & 40.51 & 40.98 & 43.57 \\
\hline & $(8.74)$ & $(8.64)$ & $(9.42)$ & $(9.21)$ & $(9.33)$ & $(8.74)$ \\
\hline \multirow[t]{2}{*}{ Median Per Cap. Income } & 31.83 & 25.96 & 27.53 & 38.56 & 40.13 & 36.24 \\
\hline & $(17.72)$ & $(10.87)$ & $(13.12)$ & $(19.27)$ & $(19.86)$ & $(12.68)$ \\
\hline \multirow[t]{2}{*}{ Homeowner $(\%)$} & 66.39 & 68.70 & 70.76 & 67.89 & 62.63 & 70.33 \\
\hline & $(24.66)$ & $(23.21)$ & $(23.94)$ & $(27.35)$ & $(28.04)$ & $(24.37)$ \\
\hline \multirow[t]{2}{*}{ Female $(\%)$} & 51.11 & 50.82 & 50.90 & 51.65 & 51.56 & 50.72 \\
\hline & $(6.07)$ & $(6.16)$ & $(6.49)$ & $(6.64)$ & $(6.37)$ & $(5.55)$ \\
\hline \multirow[t]{2}{*}{ Black or Hispanic $(\%)$} & 31.32 & 16.50 & 22.78 & 39.62 & 18.91 & 4.86 \\
\hline & $(33.52)$ & $(24.14)$ & $(30.77)$ & $(34.04)$ & $(25.23)$ & $(8.45)$ \\
\hline \multirow[t]{2}{*}{ College Education (\%) } & 21.25 & 14.92 & 17.58 & 26.15 & 29.71 & 24.93 \\
\hline & $(15.97)$ & $(11.55)$ & $(13.41)$ & $(16.50)$ & $(17.31)$ & $(12.09)$ \\
\hline \multirow[t]{2}{*}{ Distance to Nearest Port (mi.) } & 72.55 & 122.84 & 22.83 & 16.29 & 22.36 & 46.10 \\
\hline & $(85.85)$ & $(68.47)$ & $(17.73)$ & $(18.81)$ & $(27.75)$ & $(25.30)$ \\
\hline Observations & 9,689 & 4,811 & 8,164 & 3,916 & 4,982 & 921 \\
\hline
\end{tabular}

Note: Observations at the block group level. Under summary statistics we report the means with standard deviations in parentheses. 
Table A3: Summary Statistics

\begin{tabular}{|c|c|c|c|c|c|c|}
\hline & (1) & (2) & (3) & (4) & (5) & (6) \\
\hline States: & North Carolina & New Jersey & Ohio & Oregon & Pennsylvania & Louisiana \\
\hline \multicolumn{7}{|l|}{ A. Prediction Results } \\
\hline$\%$ Port Approval & $60.56 \%$ & $63.27 \%$ & $59.70 \%$ & $61.60 \%$ & $60.38 \%$ & $59.79 \%$ \\
\hline \multicolumn{7}{|l|}{ B. Summary Statistics } \\
\hline \multirow[t]{2}{*}{ Democratic Vote Share (\%) } & 46.41 & 58.54 & 45.82 & 54.52 & 49.14 & 43.38 \\
\hline & $(15.45)$ & $(13.13)$ & $(15.06)$ & $(17.78)$ & $(18.37)$ & $(20.23)$ \\
\hline \multirow[t]{2}{*}{ Median Age } & 40.52 & 41.09 & 40.67 & 41.60 & 41.52 & 38.31 \\
\hline & $(9.50)$ & $(9.34)$ & $(9.03)$ & $(9.81)$ & $(9.08)$ & $(9.21)$ \\
\hline \multirow[t]{2}{*}{ Median Per Cap. Income } & 27.24 & 39.17 & 27.63 & 30.35 & 30.26 & 25.46 \\
\hline & $(14.23)$ & $(19.97)$ & $(13.46)$ & $(13.16)$ & $(14.33)$ & $(13.42)$ \\
\hline \multirow[t]{2}{*}{ Homeowner $(\%)$} & 64.47 & 64.78 & 65.37 & 62.97 & 68.33 & 63.68 \\
\hline & $(23.26)$ & $(29.17)$ & $(24.53)$ & $(23.09)$ & $(23.14)$ & $(23.61)$ \\
\hline \multirow[t]{2}{*}{ Female $(\%)$} & 51.48 & 51.36 & 51.23 & 50.46 & 51.27 & 51.40 \\
\hline & $(6.44)$ & $(6.37)$ & $(6.24)$ & $(5.97)$ & $(6.33)$ & $(7.46)$ \\
\hline \multirow[t]{2}{*}{ Black or Hispanic $(\%)$} & 30.77 & 33.41 & 18.26 & 13.34 & 19.35 & 41.46 \\
\hline & $(26.65)$ & $(31.88)$ & $(25.98)$ & $(14.14)$ & $(28.34)$ & $(32.93)$ \\
\hline \multirow[t]{2}{*}{ College Education (\%) } & 18.96 & 26.12 & 16.95 & 22.67 & 19.86 & 15.49 \\
\hline & $(14.68)$ & $(15.48)$ & $(13.61)$ & $(15.21)$ & $(14.08)$ & $(13.57)$ \\
\hline \multirow[t]{2}{*}{ Distance to Nearest Port (mi.) } & 136.08 & 12.27 & 79.59 & 41.53 & 68.41 & 49.29 \\
\hline & $(79.41)$ & $(9.52)$ & $(60.57)$ & $(46.66)$ & $(48.88)$ & (58.19) \\
\hline Observations & 6,137 & 6,316 & 9,234 & 2,628 & 9,739 & 3,463 \\
\hline
\end{tabular}

Note: Observations at the block group level. Under summary statistics we report the means with standard deviations in parentheses. 
Table A4: Summary Statistics

\begin{tabular}{|c|c|c|c|c|}
\hline & (1) & (2) & (3) & (4) \\
\hline States: & South Carolina & Virginia & Washington & Wisconsin \\
\hline \multicolumn{5}{|l|}{ A. Prediction Results } \\
\hline$\%$ Port Approval & $59.52 \%$ & $61.77 \%$ & $62.67 \%$ & $60.20 \%$ \\
\hline \multicolumn{5}{|l|}{ B. Summary Statistics } \\
\hline \multirow[t]{2}{*}{ Democratic Vote Share (\%) } & 43.32 & 52.91 & 57.65 & 49.71 \\
\hline & $(12.80)$ & (18.42) & (14.54) & $(14.21)$ \\
\hline \multirow[t]{2}{*}{ Median Age } & 40.69 & 40.26 & 39.97 & 40.68 \\
\hline & $(9.99)$ & $(9.50)$ & $(9.34)$ & $(8.92)$ \\
\hline \multirow[t]{2}{*}{ Median Per Cap. Income } & 25.87 & 35.65 & 34.98 & 29.68 \\
\hline & $(14.11)$ & $(25.38)$ & (16.69) & (11.54) \\
\hline \multirow[t]{2}{*}{ Homeowner (\%) } & 67.64 & 66.92 & 64.97 & 67.36 \\
\hline & $(21.96)$ & $(25.38)$ & $(24.51)$ & $(23.81)$ \\
\hline \multirow[t]{2}{*}{ Female $(\%)$} & 51.69 & 51.02 & 50.09 & 50.35 \\
\hline & $(6.99)$ & $(6.67)$ & $(5.71)$ & $(5.41)$ \\
\hline \multirow[t]{2}{*}{ Black or Hispanic (\%) } & 35.43 & 27.68 & 14.90 & 14.48 \\
\hline & $(27.39)$ & $(25.13)$ & $(16.37)$ & $(24.49)$ \\
\hline \multirow[t]{2}{*}{ College Education (\%) } & 17.32 & 24.78 & 23.64 & 18.81 \\
\hline & $(13.65)$ & $(17.20)$ & $(15.53)$ & (12.19) \\
\hline \multirow[t]{2}{*}{ Distance to Nearest Port (mi.) } & 103.32 & 57.00 & 44.03 & 44.69 \\
\hline & $(65.73)$ & $(66.04)$ & $(72.27)$ & $(44.79)$ \\
\hline Observations & 3,059 & 5,324 & 9,558 & 4,475 \\
\hline
\end{tabular}

Note: Observations at the block group level. Under summary statistics we report the means with standard deviations in parentheses. 